\title{
Sexing of mouse eggs at the first cleavage division by the use of $\mathrm{C}$-staining method
}

\author{
Midori Yoshizawa, Takashi Muramatsu and Akira Окamoto \\ Department of Animal Breeding, Faculty of Agriculture, \\ Utsunomiya University, Utsunomiya 321
}

\begin{abstract}
Summary. One-celled eggs were recovered from mated, colchicine-primed dd female mice, and chromosome preparations were made by the air-drying and C-staining methods. Their mitotic stages were mostly at late prometaphase with two haploid groups of chromosomes and at early metaphase, a stage of syngamy, and partly at the chromatid stage of metaphase. The Y, a small chromosome with no C-band, was distinguished not only at the chromatid stage of metaphase but also at the other stages above-mentioned. Out of 2,053 eggs examined 767 eggs could be sexed, sexing rate being $37.4 \%$. Of these, 334 eggs were identified as males and 433 females, with a sex ratio of $43.5 \%$ males. The sex ratio was further classified according to the stages above-mentioned. Sex ratio before syngamy was significantly higher than that at syngamy and the chromatid stage of metaphase.
\end{abstract}

(Japan. J. Anim. Reprod., 31, 78-83)

\section{Introduction}

Sex ratios at different stages of embryonic development in both mammals and birds are now possible to be measured on the basis of karyological sexing of the conceptuses. The cytological marker of Sтісн \& $\mathrm{Hsu}^{1)}$ for sexing somatic cells and the air-drying method of $\mathrm{TARKOWSKI}^{2)}$ for preparing metaphase plates from cleaving eggs and blastocysts are applicable in the mouse.

Sexing rate, however, is considerably lowered in earlier stages of development, especially at the first cleavage division, because of the limited number of the component cells and, so, infrequent occurence of analyzable metaphase plates in these stages. To cover this fault we attempted to use the known difference in C-band pattern between the $\mathrm{Y}$ and the other chromosomes as a marker for sexing first cleavage mouse eggs. The results are described in this papar.

\section{Materials and Methods}

Virgin female dd mice were kept in an airconditioned room with $14 \mathrm{~h}$ of light and $10 \mathrm{~h}$ of darkness. They were placed with fertile dd males (1 female per male), and checked every morning for vaginal plug. Mated females were injected ip with $0.3 \mathrm{ml}$ of $0.025 \%$ colchicine solution from 13 to $15 \mathrm{~h}$ after the middle of the previous dark period. They were killed 8 to $10 \mathrm{~h}$ later. Oviduct was exiced and immediately placed in Tyrode solution kept at $37 \mathrm{C}$. Under a stereoscopic microscope, it was carefully torn with dissecting fine needles. Eggs were collected and transferred in fresh Tyrode solution. Hypotonic treatment in sodium citrate solution, fixing by dropping acetic alcohol and air-drying were made by the method of TARKOwski ${ }^{2}$.

Several C-band staining methods are available, most involving a step of alkaline treatment for denaturation of chromosome DNA. An alternative simple method was developed 
by $\mathrm{T}_{\mathrm{AKAGI}}{ }^{3)}$, who made denaturation in hot distilled water. We modified his method for use in mouse eggs at the first cleavage division. The procedure adapted was as follows: Slides, preferable to spend one to three days after air-drying, were incubated in hot distilled water for 10 to $15 \mathrm{~min}$ at $92 \pm 2 \mathrm{C}$, then in $2 \times \mathrm{SSC}$ for $15 \mathrm{~min}$ at $65 \mathrm{C}$. They were rinsed in distilled water, and stained with $1 \%$ Giemsa solution at $\mathrm{pH} 6.4$ for $1 \mathrm{~h}$. They were rinsed again with tap water, air-dried and examined with a light microscope.

Chromosome preparations, both conventional and $\mathrm{C}$-stained, were also made from femur bone marrow cells taken from both sexes of adult dd mice. The method adapted accorded largely with that of FORD \& WOOL$\mathrm{LAM}^{4}$. C-staining was made by our modification above-mentioned.

\section{Results}

A total of 2,530 eggs were obtained from 225 mated and colchicine-primed females, the recovery rate to the number of corpora lutea being $99.7 \%$. Of these, 2,053 eggs (81.1\%) were still held in the 1-cell stage and apparently normal in shape (Table 1). They all were examined cytologically. The others were 2-cell eggs and abnormal ones. (The

Table 1. Recovery and sexing rates of 1-cell eggs of mice

\begin{tabular}{lc}
\hline \hline No. of: & \\
female mice & 225 \\
corpora lutea & 2,538 \\
eggs recovered & 2,530 (recovery rate (r) $^{1)} .7 \%$ ) \\
1-cell eggs & 2,053 \\
eggs sexed & 767 (sexing rate $: 37.4 \%)$ \\
males & 334 (sex ratio $\left.{ }^{3)}: 43.5 \%\right)$ \\
females & 433
\end{tabular}

1) No. of eggs $/$ No. of corpora lutea $\times 100$.

2) No. of eggs sexed/No. of 1 -celled eggs $\times 100$.

3) Percentage of male. incidence of various types of abnormal eggs in our dd mice has appeared in a previous $\operatorname{papar}^{5)}$.)

Mitotic figures of the 1-cell eggs showed their stages ranging from pronuclear to anaphase, mostly being at late prometaphase and early metaphase, and partly at the chromatid stage of metaphase (the designation of the stages of mitosis accords with that of KAUF$\left.\mathrm{MAN}^{(3)}\right)$. Namely in most of the mitoses examined chromosomes were less condensed and undivided into distinctive chromatids. They were frequently showed as two haploid groups originating from male and female pronuclei.

In most of our conventional Giemsa-stained preparations it was difficult and frequently impossible to ascertain the presence of the two or three smallest chromosomes (a criterion for sexing) in a given mitotic plate because the length of individual chromosomes was unstable in these earlier stages of mitosis and more than three chromosomes with similar short lengths appeared very often.

In C-stained chromosome preparations from bone marrow cells of dd mice, a reddish purple region (C-band) appeared near the centromere of individual chromosomes except a small chromosome in male cells. This exceptional chromosome had its arms stained slightly darker than those of the other component chromosomes, but no C-band was observed throughout its length. These findings showed that this chromosome is the Y.

A small chromosome comparable to the $\mathrm{Y}$ was showed also in $\mathrm{C}$-stained mitotic plates of 1-cell eggs at the stages of late prometaphase and early metaphase as well as the chromatid stage of metaphase. Fig. 1 represents two haploid groups of chromosomes in a late prometaphase plate. The small 
Table 2. Sex ratios classified by the stages of first cleavage mitosis of mouse eggs

\begin{tabular}{|c|c|c|c|c|}
\hline \multirow{2}{*}{ Stage of mitosis } & \multicolumn{3}{|c|}{ No. of } & \multirow{2}{*}{$\begin{array}{l}\text { Sex ratio } \\
(\% \text { male })\end{array}$} \\
\hline & Males & Females & Total & \\
\hline Late prometaphase & 265 & 308 & 573 & $46.2 \%$ \\
\hline Early metaphase to chromatid stage & 69 & 125 & 194 & $35.5 \% *$ \\
\hline Total & 334 & 433 & 767 & $43.5 \% *$ \\
\hline
\end{tabular}

* Significance of deviation from equality: $P<0.001$.

chromosome that has no $\mathrm{C}$-band is present in the groups on the right in Fig. 1. Individual chromosomes of this group are less condensed than those of the other group. Therefor the former group is certainly of paternal origin. Fig. 2 shows a diploid group of chromosomes in an early metaphase plate, where paternal and maternal chromosomes are fused. Two small chromosomes, both with distinct $\mathrm{C}$ bands, are present, but there is no chromosome comparable to the Y.

On the basis of these findings, we made sexing of the 1-cell eggs by confirming the presence (male) or absence (female) of the small unpaired chromosome that has no $\mathrm{C}$ band in a plate of the complete diploid or two haploid chromosomes. In C-stained preparations the arms of individual chromosomes were not heavily stained, and so overlapping of chromosomes, if present, could be easily discerned. Many preparations, however, were discarded because their chromosomes were abnormal in number or shape and because their chromosomes were not satisfactorily dispersed.

As shown in Table 1, 767 eggs, 37.4 percentage of all the 1-cell eggs examined, could be sexed. Of these 334 were identified as males and 433 females, sex ratio being $43.5 \%$ and significantly deviating from equality $(P<$ 0.001 ). The sex ratio was further classified by the phases of mitoses for which sexing was made (Table 2). Eggs sexed at late pro- metaphase of two haploid groups of chromosomes are 573 , of which 265 are males and 308 females. A sex ratio of $46.2 \%$ is likewise in favor of female, but deviation is not significant statistically. From early metaphase to chromatid stage are sexed 194 eggs with 69 males and 125 females. A sex ratio of $35.5 \%$ is highly significant in deviation $(P<0.001)$. The difference in sex ratio between the two stages of mitosis is significant $(P<0.01)$.

\section{Discussion}

STICH \& $\mathrm{Hsu}^{1)}$ proposed a simple cytological criterion for sexing mouse somatic cells, which depends on the presence of the two (female) or three (male) smallest chromosomes in the complete diploid chromosomes. This was used by VICKERS ${ }^{7)}$ for sexing mouse blastocysts and by $\mathrm{KAUFMAN}^{8)}$ for mouse eggs at the first cleavage division. As stated by STICH \& $\mathrm{Hsu}^{1)}$, the adaptation of this criterion is confined only to metaphase plate, which is, strictly speaking, the chromatid stage of metaphase when chromosomal condensation and form become stable. This limitation greatly lowers sexing rate in less advanced early stages of development, when the numbers of the component cells and analyzable metaphase plates are extremely limited. KaUfman' ${ }^{8)}$ data shows successful sexing rate to be 13.6 percentage of the number of the 1-cell eggs examined, whereas VICKers ${ }^{7)}$ obtained a rate of about $44 \%$ in the sexing of 
32- to 64-cell blastocysts.

Additionally, several workers reported strain specific differences in length of the $\mathrm{Y}$ chromosome. SofUni \& $M_{A K I N O}{ }^{9)}$ found an unusually long $\mathrm{Y}$ chromosome in a random bred dd/Om male mouse. Yoshida \& KoDAMA $^{10)}$ found a $\mathrm{Y}$ chromosome shorter than No. 19 chromosome in BALB/cAn.

The findings above-mentioned show that sexing, especially of first cleavage eggs, must be made on the basis of the exact determination of the Y. Many authors applied various banding methods to mouse somatic chromosomes to identify the homologous pairs of chromosomes, and reported the exceptional stainability of the Y. CHEN \& RUDDLE ${ }^{11)}$ reported that the $\mathrm{Y}$ is unusual in that it has no distinctively staining $\mathrm{C}$-band, and is stained overall with a density intermediate between centrometric heterochromatin and euchromatin. Pardue \& Gall, ${ }^{12)}$ TAKAGI $^{3)}$ and Dev et $a l .{ }^{13)}$ are also in agreement in that the $\mathrm{Y}$ has no $\mathrm{C}$-band in mice. On the other hand, some authors reported polymorphism of C-bands of chromosomes in mouse somatic cells. FOREJT $^{14)}$ found some chromosomes showing considerablly reduced or enlarged $\mathrm{C}$-bands in laboratory and wild mice. Dev et al. ${ }^{15)}$ found eight pairs of chromosomes having little or no C-band in $M . m$. molossinus. However, the consistency of C-band patterns in a group of small chromosomes was shown by Yoshida \& KodAma, ${ }^{10)}$ who found that the $\mathrm{Y}$ has no $\mathrm{C}$ band but Nos. 18 \& 19 chromosomes have Cband in all the 17 strains of mice examined.

Our observations that the $\mathrm{Y}$ of bone marrow cells of male dd mice has no C-band are in good agreement with those by previous authors above-mentioned. A modification of the $\mathrm{C}$-staining method of $\mathrm{T}_{\mathrm{AKAGI}}{ }^{3)}$ was useful for identifying the $\mathrm{Y}$ at the stages of late prometaphase and early metaphase as well as the chromatid stage of metaphase. This rised the rate of successful sexing at the first cleavage mitosis of mouse eggs.

As shown by other workers, two haploid groups with asynchronous chromosome condensation were still distinctive at the stage of late prometaphase. Using the T163H chromosome marker, DonahuE ${ }^{16)}$ demonstrated that the larger group of less condensed chromosomes is derived from the fertilizing sperm. Thus the $\mathrm{Y}$, if present, has to be found out in this larger group of male origin. This was confirmed in the present study.

Primary sex ratio was $50.0 \%$ in PDE mouse blastocysts by Vickers, ${ }^{7)}$ and $50.4 \%$ in 1 -cell eggs of CFLP mouse by $\mathrm{K}_{\text {AUfMan }}{ }^{8)}$. A sex ratio of $44.8 \%$ of our dd mice is significantly lower than those. In this study the sex ratio was classified according to the substages of mitosis; late prometaphase, early metaphase and the chromatid stage of metaphase. Early metaphase is a critical stage at which two chromosome groups of male and female origins are fused and so named the stage of "syngamy" by Kaufman ${ }^{6)}$ and others. It is interesting that the sex ratio before syngamy was significantly higher than that at syngamy and the chromatid stage of metaphase.

\section{References}

1) Sтicн HF \& TC Hsu: Exptl. Cell Res., 20, 248, 1960.

2) Tarkowski, AK: Cytogenetics, 5, 394, 1966.

3) Takagi N: Japan. J. Genetics, 46, 361, 1971.

4) Ford EHR \& DHM Woollam: Stain Techn., 38, 271, 1963.

5) Shimane $M$ \& $T$ Muramatsu: Bull. Agric. Utsunomiya Univ., 10 (3), 55, 1979.

6) Kaufman MH: J. Cell Sci., 12, 799, 1973.

7) Vickers AD: J. Reprod. Fert., 13, 375, 1967.

8) Kaufman MH: J. Reprod. Fert., 35, 67, 1973.

9) Sofuni T \& S Makino: Chrom. Inform, Serv., 7, 15, 1966. 
10) Yoshida MC \& Y Kodama: Cytogenet. Cell Genet., 35, 51, 1983.

11) Chen TR \& FH Ruddle: Chromosoma (Berl.), 34, 51, 1971.

12) Pardue ML \& JG Gall: Science, 168, 1356, 1970.

13) Dev VG, DA Miller \& OJ Miller: Genetics, 75, 663, 1973.
14) Forejt J: Chromosoma (Berl.), 43, 187, 1973.

15) Dev VG, DA Miller, R Tantrayahi, RR Schreck, TH Roderick, BF Erlanger \& OJ Miller: Chromosoma, (Berl.), 53, 335, 1975.

16) Donahue RP: Proc. Nat. Acad. Sci. USA, 69, 74, 1972.

(Received March 25, 1985)

\section{C-バンド染色法を用いたマウス受精卵の性判別}

\section{吉沢 緑・村松 隆・岡本 昭}

(宇都宮大学農学部家畜育種繁殖学教室)

dd 系アルビノマウスの受精卵について，Y-染色体の 識別により正確な性判別を行ならこと, および判別率を 高めることを企図した。交尾を確認した雌マウスにコル ヒチンを腹腔内注射し, 卵を回収した。染色体標本作製 は, TARKOWSKI の空気乾燥法で行ない, Y-染色体と他 の染色体を区別するために，Cーバンド染色を行なった。 C-バンド染色法は, 高木の方法に若干の修正を加えた ものである。1-細胞期卵の分裂像は, 雌雄前核由来の 2 群の半数の染色体を示す late prometaphase と, それ らの融合初期である early metaphase (syngamy) を示
すものが多く，染色分体の形成を示す chromatid stage のものは，わずかであった。Y-染色体は C-バンドを有 しない小型染色体として認められ，前述のどの分裂段階 でも他の染色体と区別し得た。2,053 個の 1-細胞期卵の らちの 767 個 $(37.4 \%)$ で性判別ができ, 雄 334, 雌 433, 性比 (雄率) は $43.5 \%$ で雌への偏りがみられた $(P<0.001)$ 。性比を前述の各分裂段階に分けて比較する と, syngamy 前の性比は, $46.2 \%$ で, 偏りは有意でな かった。

\section{Explanation of Figures}

Fig. 1. Two complete haploid groups of chromosomes in a plate of late prometaphase at the first cleavage division in a fertilized mouse egg. The chromosomes of one group (on the right) are less condensed than those of the other group (on the left). The Y, a small chromosome with no C-band (long arrow), is distinctive from two small autosomes with C-bands (short arrows), this egg being sexed as male. C-staining after air-drying.

Fig. 2. A complete diploid group of chromosomes in a plate of early metaphase (syngamy) at the first cleavage division in a fertilized mouse egg. Individual chromosomes, including two small autosomes (short arrows), show various sizes of C-bands. The $\mathrm{Y}$ is not observable among all 40 chromosomes, this egg being sexed as female. C-band staining after air-drying. 


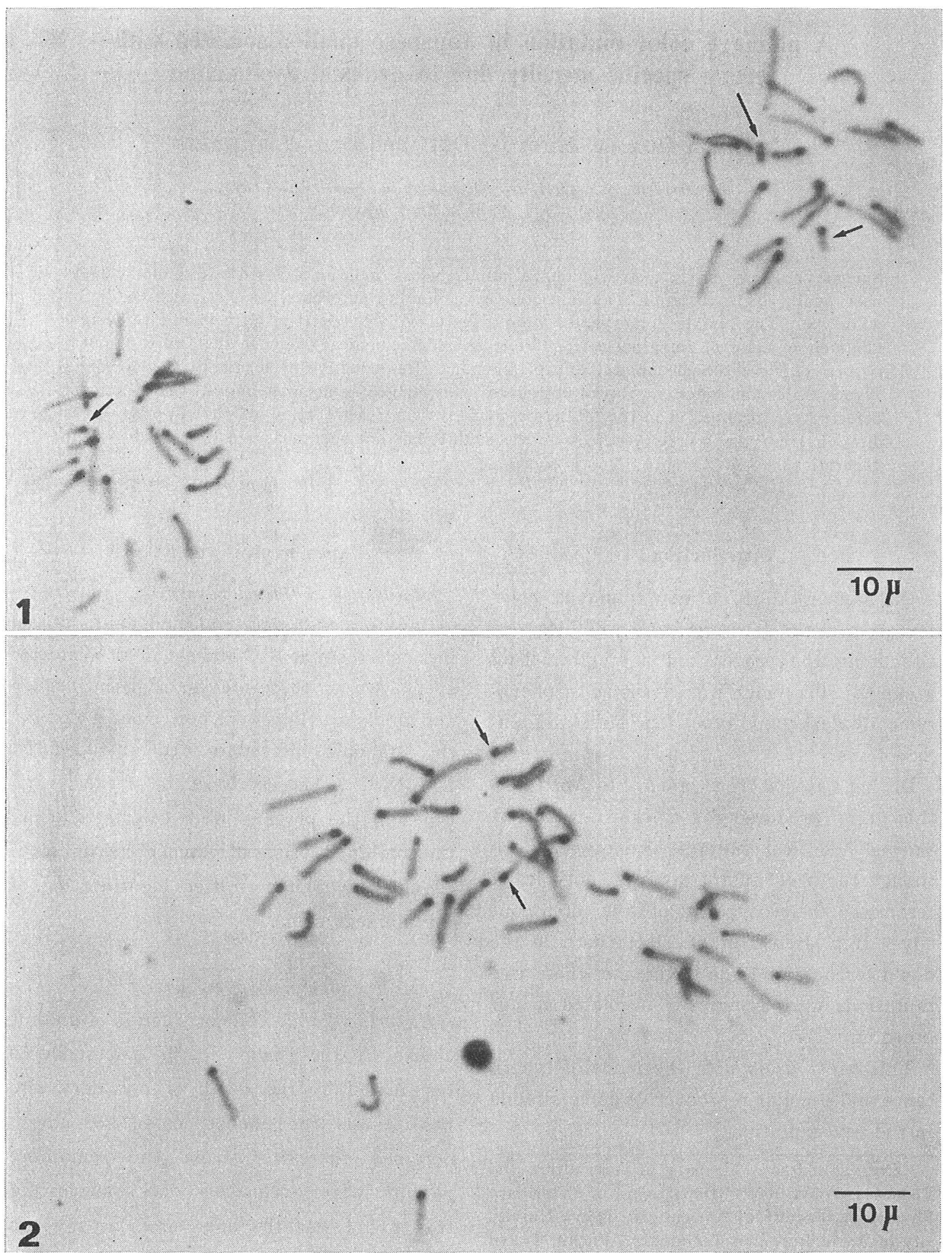

